\title{
Periphytic ciliate colonization: annual cycle and responses to environmental conditions
}

\author{
Jun Gong ${ }^{1}$, Weibo Song ${ }^{1, *}$, Alan Warren ${ }^{2}$ \\ ${ }^{1}$ Laboratory of Protozoology, Ocean University of China, Qingdao 266003, PR China \\ ${ }^{2}$ Department of Zoology, Natural History Museum, Cromwell Road, London SW7 5BD, UK
}

\begin{abstract}
Glass slides were used as artificial substrates for collecting periphytic ciliates from scallop-farming waters of Jiaozhou Bay near Qingdao (China) over a period of 1 yr. A total of 37 ciliate species, about half of which belong to the orders Hypotrichida and Cyrtophorida, were identified using living observation and silver impregnation methods. Peaks of ciliate abundance and biomass occurred in November, mainly due to the suctorian Corynophrya lyngbyi, while sessile peritrichs (especially Pseudovorticella sinensis, Zoothamnium duplicatum and Z. plumula) dominated the ciliate communities during August. Vagile ciliates had low abundance and biomass despite accounting for a large proportion of the species richness. Almost no typical periphytic ciliates were detected in the winter months (from January to March). Twelve dominant species showed clear succession over the year and were found to correlate with a variety of environmental variables. Univariate and multivariate analyses were performed in order to explore the relationship between ciliate community and environmental conditions (temperature, salinity, $\mathrm{pH}$, dissolved inorganic nitrogen, soluble reactive phosphate, dissolved oxygen, chlorophyll $a$, turbidity). Diversity and evenness indices were found to be relatively independent of physico-chemical factors, whereas species richness and the ratio of biomass to abundance were strongly related to nutrients. Multivariate analyses revealed that temperature, nutrients and salinity may best explain the changes in community structure of ciliates colonizing the glass slides.
\end{abstract}

KEY WORDS: Periphytic ciliate - Temporal variations - Environmental stress - Marine biofilm · Microbial ecology $\cdot$ Scallop farming $\cdot$ Jiaozhou Bay

Resale or republication not permitted without written consent of the publisher

\section{INTRODUCTION}

Ciliates are important components of the aquatic ecosystem and play a crucial role in the functioning of microbial food webs (Finlay et al. 1979, 1988, Azam et al. 1983, Pratt \& Crains 1985, Sherr \& Sherr 1987, Caron \& Goldmann 1990). Several ciliates inhabit environments that are unfavorable to most metazoans and some can tolerate what would be extreme environmental conditions to macrofauna (Fenchel 1969, Patterson et al. 1989). Furthermore, with their rapid growth and delicate external membranes, ciliates may react more quickly to environmental changes than most other eukaryotic organisms and can thus serve as bioindicators of water pollution (Cairns et al. 1972,
Dale 1991, Foissner et al. 1992, Pratt \& Balczon 1992, Al-Rashid \& Sleigh 1995, Coppellotti 1998).

Glass slides may be used as artificial substrates that allow microorganisms to form a periphyton or biofilm, in which periphytic ciliates are usually in high abundance and richness (Cairns \& Yongue 1968, Foissner et al. 1992). Compared with sampling periphytic ciliates from natural substrates such as stones (Foissner et al. 1992) and macrophytes (Baldock et al. 1983), collection using glass slides seems to be non-destructive, since most species can be observed, enumerated and even identified in vivo by observation of the whole slide under an inverted or a stereomicroscope. In addition, the species richness of ciliate communities colonizing glass slides is almost as high as those on natural 
substrates exposed to the same environmental conditions (Agamaliev 1974, Foissner et al. 1992). Differences between fauna have been detected using glass slides in different conditions (Song \& Chen 1999, Strüder-Kypke 1999, Strüder-Kypke \& Schönborn 1999, Primc-Habdija et al. 2001, Weitere et al. 2003). Moreover, recent studies have demonstrated that periphytic ciliates are strongly related to effluent quality in wastewater treatment processes (Fried et al. 2000, Martín-Cereceda et al. 2001).

Biomonitoring using ciliated protozoa is widely accepted and has many advantages: (1) they are easy to sample compared with other biota such as fish; (2) the generation times are short and they are protected from the environment by only a delicate membrane, so the potential response time to pollution events is fast; (3) periphytic species in particular are relatively immobile, and therefore good for local stress studies; (4) the increasing availability of easily used taxonomic references, and (5) artificial substrates allowing colonization can be standardized for temporal and spatial comparisons (Mohr 1952, Lee 1986, Foissner 1987, Clarke \& Warwick 1994). In the interest of using periphytic ciliates as indicators and further tracking the effects of pollution and recovery of the biotic component, it is necessary to have an adequate knowledge of the specific community structures, the relationship with environmental conditions as well as suitable indices. Such studies on marine environment, however, have rarely been carried out (Persoone 1968, Agamaliev 1974, Coppellotti \& Matarazzo 2000).

Between October 2000 and September 2001, a 1 yr baseline survey of periphytic ciliates colonizing glass slides was carried out in a scallop-farming area of Jiaozhou Bay, where the most severe form of pollution is the overload of nutrients, especially inorganic nitrogen and phosphorus (Ma et al. 1997). The farming of scallops was responsible for introducing great varia-

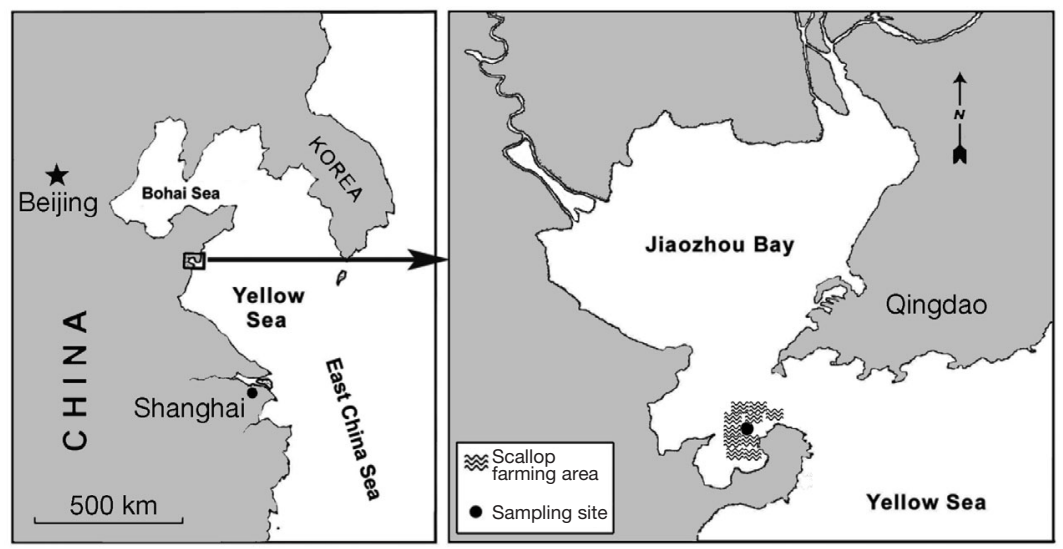

Fig. 1. Map of the study area tions of environmental factors in the study area; thus, it offered an interesting opportunity for a biota-environment analysis. The aims of this study were: (1) to document the taxonomic composition and the temporal pattern of periphytic ciliates colonizing glass slides in the scallop-farming waters; (2) to monitor the population dynamics of the periphytic ciliate communities and their responses to environmental factors and (3) to explore the possibility of using periphytic ciliate community in assessment of marine water quality.

\section{MATERIALS AND METHODS}

Study site. Jiaozhou Bay is a semi-closed bay with an area of about $400 \mathrm{~km}^{2}$ and on average a depth of $7 \mathrm{~m}$. The north of the bay receives inflows from several small rivers and the south is connected with the Yellow Sea. The sampling site was located at the centre of a scallop-farming area (about $16 \mathrm{~km}^{2}$ ) with a depth of $10 \mathrm{~m}$ (Fig. 1).

Sampling. Twenty-two samples (referred to as Oct-I, Oct-II, etc.) were collected during a 12 mo period from October 2000 to September 2001. Glass slides $(2.6 \times$ $7.6 \mathrm{~cm}$ ) were clipped to a PVC frame, and were immersed in the water at a depth of about $1 \mathrm{~m}$ below the surface. The slides were exposed as back-to-back pairs; thus, they could be split and observed directly without cleaning. Slides were placed vertically in the frames, each frame holding 20 sheets of slides. The samples were collected every $15 \mathrm{~d}$. In January and April 2001 samples were lost; therefore, at these times the sampling could only be performed irregularly.

According to Wilbert (1969), there are no significant differences between ciliate communities colonizing slides within the same frame. Thus, for every sampling date 5 replicate slides were randomly selected and then evaluated. The slides were transferred into jars containing water from the sampling site, stored in a cooling box and transported to the laboratory within $1 \mathrm{~h}$ for identification and counting.

Water temperature $(\mathrm{T})$, salinity $(\mathrm{S})$, $\mathrm{pH}$, dissolved oxygen concentration (DO) were recorded in situ with appropriate sensors (WTW) at the depth of $1 \mathrm{~m}$; turbidity was measured by a turbidimeter (Hach 2100P, Hach). One 1 of seawater was collected for laboratory analysis of dissolved inorganic nitrogen concentrations (DIN, sum of $\mathrm{NO}_{3}-\mathrm{N}, \mathrm{NO}_{2}-\mathrm{N}$ and $\mathrm{NH}_{3}-\mathrm{N}$ ) and soluble reactive phosphate (SRP) followed standard methods (APHA 1989). A further $500 \mathrm{ml}$ water sample was filtered 
through Whatman $25 \mathrm{~mm}$ GF/F filters by gentle vacuum filtration; after the extraction of the filter paper in $90 \%$ acetone for $24 \mathrm{~h}$ at $4^{\circ} \mathrm{C}$, the concentration of chlorophyll a ( $\mathrm{chl}$ a) in the supernatant was determined using a spectrophotometer (UV-1601, Shimadzu) (Talling \& Driver 1961, Jeffrey \& Humphrey 1975).

Identification and enumeration of ciliates. Species were first examined at 45-fold magnification using a stereomicroscope to observe the behavior and movement of the cells. They were then transferred using a micropipette to a clean glass slide and placed under a microscope (BH-2 Olympus) at 100- to 1250-fold magnification to reveal cell size and other morphological characters in detail (Foissner et al. 1999). Usually over 30 individuals of each morphotype were picked out with micropipette and then identified to species level using protargol (Wilbert 1975) and Chatton-Lwoff silver nitrate method (Song \& Wilbert 1995). Species identifications were made following reference to keys and guides such as Kahl (1931) and Carey (1992). The taxonomic scheme is according to Corliss (1979). Detailed morphological descriptions of most species isolated during the study have been published elsewhere (Gong et al. 2001, Hu et al. 2002, Hu et al. 2003, Ji et al. 2003, Gong \& Song 2004a,b, Hu et al. 2004, Lin et al. 2004,). The designation of species as being sessile, vagile or planktonic was made according to their mobility and the ecological niches they occupy. This approach has been used in previous studies including those by Foissner et al. $(1992,1999)$ and Coppellotti \& Matarazzo (2000).

The enumeration and measurement of ciliates in vivo was carried out under an inverted microscope as soon as possible after sampling (generally within 1 to $2 \mathrm{~h}$ ) in order to prevent significant changes in species number and composition. Using bright field illumination, 5 fields of view per slide were randomly chosen for counting. The ciliate concentrations were calculated from all 5 replicate slides to determine average cell density (ind. $\mathrm{cm}^{-2}$ ).

Biovolume estimates based on 3-dimensional measurements and approximations of shape to standard geometrical configurations (Winberg 1971) were made for most ciliate species fixed with $2 \%(\mathrm{v} / \mathrm{v})$ formalin. The volumes of individual ciliates were converted to biomass using a conversion factor of $0.14 \mathrm{pg} \mathrm{C} \mathrm{mm}^{-3}$ (Putt \& Stoecker 1989).

Data analysis of samples. Species diversity $\left(H^{\prime}\right)$ (Shannon \& Weaver 1963), evenness $(J)$ (Pielou 1969) and species richness (d) (Margalef 1968) of samples (apart from samples Jan I to March II due to low number of species present) were calculated as follows:

$$
H^{\prime}=-\sum_{i=1}^{S} P_{i}\left(\ln P_{i}\right)
$$

where $H^{\prime}=$ observed diversity index; $P_{i}=$ proportion of the total count arising from the $i$ th species; $S=$ total number of species; $J=H^{\prime} / \ln S$ and $d=(S-1) / \ln N$, where $N=$ total number of individuals.

The community structures of samples were analyzed using the PRIMER package (Plymouth Routines in Multivariate Ecological Research, Clark \& Warwick 1994). A Bray-Curtis similarity coefficient matrix was calculated on root transformed data and separate clusters were identified by hierarchical clustering (CLUSTER) and on multidimensional scaling plots (MDS). Differences between species compositions were tested by the PRIMER program ANOSIM.

The multivariate biota-environment (BIOENV) procedure (Clarke \& Ainsworth 1993) was used to explore the potential relationships between the abiotic features of water and the similarity patterns among biological samples. BIOENV functions within the PRIMER program and allows either a full search of all abiotic variable combinations or of specific subsets, e.g. all combinations containing certain variables or containing a fixed number of variables. Chl a was omitted from the environmental matrix due to its collinearity with temperature. Data for $\mathrm{NO}_{3}-\mathrm{N}, \mathrm{NO}_{2}-\mathrm{N}, \mathrm{NH}_{3}-\mathrm{N}$ and SRP were normalised by logarithmic transformation before analysis.

\section{RESULTS}

\section{Environmental conditions}

The results of the physico-chemical analyses of the water samples are shown in Table 1. The water temperature was significantly lower in winter (from January to March); salinity showed little variation (around $30 \mathrm{psu}$ ) throughout the year apart from a sharp decrease to 20 psu in late July; $\mathrm{pH}$ values ranged from 6.9 to 7.9 ; turbidities were much lower in the period from April to July, indicating much clearer waters with Sechii depths of about 1.5 to $3.3 \mathrm{~m}$; concentrations of dissolved oxygen generally exceeded $7.0 \mathrm{mg} \mathrm{l}^{-1}$ except that 2 lower values (3.8 and $4.3 \mathrm{mg} \mathrm{l}^{-1}$ ) were recorded in 2 samples in August; concentrations of chl a were much higher in the period from April to August (4.25 to $6.75 \mu \mathrm{g} \mathrm{l}^{-1}$ ) than that

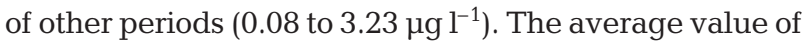
DIN over the whole year was $0.335 \mathrm{mg} \mathrm{l}^{-1}$; $\mathrm{NO}_{3}-\mathrm{N}$ (mean $0.107 \mathrm{mg} \mathrm{l}^{-1}$ ) represented $68 \%$ of the DIN in winter (mean $0.157 \mathrm{mg} \mathrm{l}^{-1}$ ), whereas $\mathrm{NH}_{3}-\mathrm{N}$ (mean $0.522 \mathrm{mg} \mathrm{l}^{-1}$ ) became the main component (89\%) of DIN (mean $0.584 \mathrm{mg} \mathrm{l}^{-1}$ ) in summer with extremely high concentrations in July and early August. The concentration of SRP ranged from 0.006 to $0.345 \mathrm{mg} \mathrm{l}^{-1}$ (mean $0.099 \mathrm{mg} \mathrm{l}^{-1}$ ) and showed no clear trend throughout the year, although there was a minor peak in early August that coincided with one for $\mathrm{NO}_{2}-\mathrm{N}$. 
Table 1. Environmental factors of sampling water between October 2000 and September 2001. Chl a: chlorophyll $a_{;}$DO: dissolved oxygen concentration; NTU: nephelometric turbidity units; S: salinity; SRP: soluble reactive phosphate; T: temperature; Tur: turbidity

\begin{tabular}{|c|c|c|c|c|c|c|c|c|c|c|}
\hline & $\begin{array}{c}\mathrm{T} \\
\left({ }^{\circ} \mathrm{C}\right)\end{array}$ & $\begin{array}{c}\mathrm{S} \\
(\mathrm{psu})\end{array}$ & $\mathrm{pH}$ & $\begin{array}{c}\text { Tur } \\
\text { (NTU) }\end{array}$ & $\begin{array}{l}\mathrm{NO}_{2}-\mathrm{N} \\
\left(\mathrm{mg} \mathrm{l}^{-1}\right)\end{array}$ & $\begin{array}{l}\mathrm{NH}_{3}-\mathrm{N} \\
\left(\mathrm{mg} \mathrm{l}^{-1}\right)\end{array}$ & $\begin{array}{l}\mathrm{NO}_{3}-\mathrm{N} \\
\left(\mathrm{mg} \mathrm{l}^{-1}\right)\end{array}$ & $\begin{array}{c}\mathrm{SRP} \\
\left(\mathrm{mg} \mathrm{l}^{-1}\right)\end{array}$ & $\begin{array}{c}\mathrm{DO} \\
\left(\mathrm{mg} \mathrm{l}^{-1}\right)\end{array}$ & $\begin{array}{c}\text { Chl a } \\
\left(\mu \mathrm{g} \mathrm{l}^{-1}\right)\end{array}$ \\
\hline Oct-I & 23.0 & 31.0 & 7.9 & 2.10 & 0.052 & 0.023 & 0.037 & 0.345 & 12.2 & 2.03 \\
\hline Oct-II & 20.0 & 31.5 & 8.2 & 3.20 & 0.055 & 0.014 & 0.046 & 0.114 & 13.8 & 1.89 \\
\hline Nov-I & 17.0 & 30.0 & 8.1 & 2.46 & 0.063 & 0.035 & 0.058 & 0.095 & 15.0 & 1.00 \\
\hline Nov-II & 10.0 & 29.0 & 7.5 & 7.82 & 0.069 & 0.063 & 0.062 & 0.076 & 16.0 & 0.80 \\
\hline Dec-I & 11.0 & 27.0 & 7.1 & 2.66 & 0.056 & 0.067 & 0.081 & 0.076 & 17.6 & 0.33 \\
\hline Dec-II & 8.0 & 28.5 & 7.4 & 5.91 & 0.015 & 0.065 & 0.030 & 0.102 & 8.5 & 0.08 \\
\hline Jan & 6.0 & 31.0 & 7.7 & 4.69 & 0.007 & 0.074 & 0.095 & 0.300 & 11.2 & 0.44 \\
\hline Feb-I & 3.5 & 30.0 & 7.6 & 4.44 & 0.001 & 0.019 & 0.111 & 0.006 & 12.1 & 0.82 \\
\hline Feb-II & 3.5 & 28.0 & 7.7 & 3.15 & 0.005 & 0.050 & 0.134 & 0.050 & 11.8 & 1.68 \\
\hline Mar-I & 4.0 & 28.0 & 7.7 & 4.21 & 0.002 & 0.063 & 0.107 & 0.008 & 10.5 & 1.59 \\
\hline Mar-II & 5.0 & 28.0 & 7.8 & 1.47 & 0.003 & 0.280 & 0.086 & 0.310 & 9.4 & 2.00 \\
\hline Apr & 8.0 & 29.0 & 7.7 & 0.85 & 0.015 & 0.230 & 0.064 & 0.060 & 12.5 & 2.03 \\
\hline May-I & 11.0 & 30.0 & 7.6 & 1.56 & 0.007 & 0.560 & 0.017 & 0.060 & 10.6 & 6.76 \\
\hline May-II & 17.0 & 29.0 & 7.2 & 1.11 & 0.006 & 0.420 & 0.021 & 0.010 & 7.5 & 4.25 \\
\hline Jun-I & 19.0 & 30.5 & 7.4 & 1.47 & 0.006 & 0.100 & 0.014 & 0.060 & 8.6 & 5.34 \\
\hline Jun-II & 16.0 & 30.0 & 7.5 & 2.29 & 0.006 & 0.380 & 0.025 & 0.040 & 6.7 & 5.43 \\
\hline Jul-I & 15.0 & 29.0 & 7.4 & 2.31 & 0.018 & 1.170 & 0.023 & 0.020 & 6.5 & 5.10 \\
\hline Jul-II & 12.0 & 30.0 & 6.9 & 2.40 & 0.009 & 0.850 & 0.010 & 0.010 & 8.5 & 5.27 \\
\hline Aug-I & 14.0 & 20.0 & 7.1 & 4.52 & 0.080 & 0.630 & 0.018 & 0.110 & 3.8 & 6.41 \\
\hline Aug-II & 13.0 & 30.0 & 7.2 & 3.13 & 0.002 & 0.041 & 0.075 & 0.025 & 4.3 & 4.96 \\
\hline Sep-I & 9.0 & 30.0 & 7.4 & 3.19 & 0.036 & 0.352 & 0.021 & 0.105 & 6.8 & 3.24 \\
\hline Sep-II & 9.0 & 29.5 & 7.4 & 5.09 & 0.046 & 0.089 & 0.036 & 0.271 & 6.5 & 2.04 \\
\hline
\end{tabular}

\section{Taxonomic composition and annual cycle of abundance and biomass}

A total of 37 ciliate species representing 10 orders and 30 genera were found during the 1 yr survey (Table 2). Hypotrichida and Cyrtophorida were the 2 orders that represented most species, accounting for 36 and $23 \%$ respectively of the species recorded; each of the other 8 orders had a comparatively low numbers of species (Table 2, Fig. 2).

The temporal variation of abundance clearly exhibited a bimodal distribution during the course of the year, with 2 peaks, 1 in autumn and 1 in summer (Fig. 3). The maximum cell densities were 1245.6 ind. $\mathrm{cm}^{-2}$ (SD = 242.1) in November 2000 and 806.5 ind. $\mathrm{cm}^{-2}$ in August 2001. The sessile suctorian Corynophrya lyngbyi was responsible for the autumn peak when it had an extremely high abundance (1173.2 ind. $\left.\mathrm{cm}^{-2}, \mathrm{SD}=98.5\right)$. Two peritrichous species, Pseudovorticella sinensis (437.5 ind. $\mathrm{cm}^{-2}, \mathrm{SD}=117.8$ ) and Zoothamnium duplicatum (366.2 ind. $\mathrm{cm}^{-2}, \mathrm{SD}=87.4$ ) gave rise to the summer peak. The sessile ciliates accounted for $83 \%$ of the total abundance for the whole year, while the vagile and planktonic ciliates accounted for 16 and $1 \%$ respectively (Fig. 4).

Biomass variation did not follow the bimodal pattern as abundance. A single peak for biomass (128 $\mu \mathrm{g} \mathrm{C}$ $\mathrm{cm}^{-2}$ ) occurred in November 2000, corresponding to the abundance peak (Fig. 3). The peak abundance in summer 2001 that was due to the 2 peritrich species did not, however, result in a distinct peak for biomass. This is mainly due to the smaller biovolume of Pseudovorticella sinensis and Zoothamnium duplicatum relative to Corynophrya lyngbyi (50 to 70 vs. 110 to $130 \mu \mathrm{m}$ in cell length). The sessile ciliates accounted for $89 \%$ of the total biomass for the whole year, the vagile and planktonic ciliates accounted for only 9 and $2 \%$, respectively (Fig. 4 ).

The species number of ciliates in the samples varied significantly with respect to seasons. The lowest species numbers were observed in the winter months (from January to March 2001), when there was usually 1 planktonic ciliate Uronema marinum; species numbers were relatively higher in spring, summer and late autumn despite of minor fluctuations, with 2 peaks in December 2000 (11 species) and July 2001 (14 species) (Fig. 3). The variation in species numbers was mainly due to the vagile ciliates, the cumulative total of which accounted for $73 \%$ during the period of sampling (Fig. 4).

There were 12 species the individual abundances of which exceeded $30 \%$ of the total at some point during the year. These were: Orthodonella hamatus, Holosticha heterofoissneri, Hartmannula angustipilosa, Trochilia sigmoides, Pseudokeronopsis qingdaoensis, Acineta tuberosa, Amphileptus litonotiformis, Coryno- 
Table 2. List of the species of ciliates recorded in 22 samples, including biohabit (Se: sessile; V: vagile; P: planktonic), body size (length $\times$ width in $\mu \mathrm{m}$ ), and degree of average abundance $\left(+=0-10\right.$ ind. $\mathrm{cm}^{-2} ;++=10-100$ ind. $\mathrm{cm}^{-2} ;+++=100-400$ ind. $\mathrm{cm}^{-2}$; $++++=$ over 400 ind. $\mathrm{cm}^{-2}$ )

\begin{tabular}{|c|c|c|c|}
\hline Species & Biohabit & Body size & Abundance \\
\hline \multicolumn{4}{|l|}{ ORDER: Haptorida } \\
\hline Chaenea teres (Dujardin, 1841) & $\mathrm{P}$ & $100-400 \times 12-40$ & + \\
\hline Lacrymaria marinum Kahl, 1933 & $\mathrm{~V}$ & $200-300 \times 20-40$ & + \\
\hline \multicolumn{4}{|l|}{ ORDER: Prostomatida } \\
\hline Holophrya oblonga Maupas, 1883 & $\mathrm{~V}$ & $300-500 \times 30-50$ & + \\
\hline Placus salinus Dietz, 1964 & $\mathrm{~V}$ & $40-45 \times 20-40$ & + \\
\hline \multicolumn{4}{|l|}{ ORDER: Pleurostomatida } \\
\hline Amphileptus litonotiformis Song, 1991 & $\mathrm{~V}$ & $120-220 \times 50-80$ & + \\
\hline Litonotus paracygnus Song, 1994 & $\mathrm{~V}$ & $150-250 \times 30-60$ & + \\
\hline \multicolumn{4}{|l|}{ ORDER: Cyrtophorida } \\
\hline Aegyriana oliva Deroux, 1974 & $\mathrm{~V}$ & $80-100 \times 60-70$ & + \\
\hline Brooklynella sinensis Gong \& Song, 2005 & $\mathrm{~V}$ & $40-50 \times 20-30$ & + \\
\hline Chlamydonella pseudochilodon Deroux, 1976 & $\mathrm{~V}$ & $30-75 \times 20-50$ & + \\
\hline Dysteria derouxi Gong \& Song, 2004 & $\mathrm{~V}$ & $100 \times 40$ & + \\
\hline Hartmannula angustipilosa, Deroux \& Dragesco, 1968 & $\mathrm{~V}$ & $40-80 \times 20-50$ & + \\
\hline Hartmannula derouxi Gong \& Song, 2004 & $\mathrm{~V}$ & $60-120 \times 30-70$ & + \\
\hline Hyросота acinetarum, Collin, 1907 & $\mathrm{~V}$ & $30-50 \times 15-25$ & + \\
\hline Trochilia sigmoides Dujardin, 1841 & $\mathrm{~V}$ & $20-30 \times 10-18$ & + \\
\hline Trochilioides recta $(\mathrm{Kahl}, 1928)$ & $\mathrm{V}$ & $40-60 \times 20-30$ & + \\
\hline \multicolumn{4}{|l|}{ ORDER: Nassulida } \\
\hline Orthodonella gutta (Cohn, 1866) Kahl, 1931 & $\mathrm{~V}$ & $140-200 \times 60-100$ & ++ \\
\hline \multicolumn{4}{|l|}{ ORDER: Suctorida } \\
\hline Acineta tuberosa, Ehrenberg, 1834 & $\mathrm{Se}$ & $180-200 \times 40-50$ & ++ \\
\hline Corynophrya lyngbyi (Ehrenberg, 1833) & $\mathrm{Se}$ & $110-130 \times 80-90$ & ++++ \\
\hline \multicolumn{4}{|l|}{ ORDER: Peritrichida } \\
\hline Pseudovorticella sinensis Ji, Song \& Al-Rasheid, 2003 & Se & $50-60 \times 35-45$ & ++++ \\
\hline Zoothamnium duplicatum Kahl, 1933 & $\mathrm{Se}$ & $70 \times 40$ & +++ \\
\hline Zoothamnium plumula, Kahl, 1933 & $\mathrm{Se}$ & $50-70 \times 30-40$ & +++ \\
\hline \multicolumn{4}{|l|}{ ORDER: Scuticociliatida } \\
\hline Pleuronema coronatum Kent, 1881 & $\mathrm{P}$ & $50-70 \times 30-40$ & + \\
\hline Uronema marinum Dujardin, 1841 & $\mathrm{P}$ & $30-40 \times 25-28$ & + \\
\hline \multicolumn{4}{|l|}{ ORDER: Hypotrichida } \\
\hline Aspidisca leptaspis Fresenius, 1865 & $\mathrm{~V}$ & $60-80 \times 40-50$ & + \\
\hline Aspidisca steini (Buddenbrock, 1920) & $\mathrm{V}$ & $20-35 \times 15-27$ & + \\
\hline Diophrys scutum (Dujardin, 1841) & $\mathrm{P}$ & $140-200 \times 70-100$ & ++ \\
\hline Euplotes rariseta Curds et al. ,1974 & $\mathrm{V}$ & $30-40 \times 20-25$ & + \\
\hline Euplotes vannus, (Müller, 1786) & $\mathrm{V}$ & $90-140 \times 60-80$ & + \\
\hline Holosticha bradburyae Gong et al., 2001 & $\mathrm{~V}$ & $150-320 \times 25-75$ & + \\
\hline Holosticha diademata, (Rees, 1883) Kahl, 1932 & $\mathrm{~V}$ & $80-90 \times 28-50$ & + \\
\hline Holosticha heterofoissneri Hu \& Song, 2001 & $\mathrm{~V}$ & $115-135 \times 32-45$ & + \\
\hline Oxytricha enigmatica Dragesco \& Dragesco-Kernéis, 1986 & $\mathrm{P}$ & $80-100 \times 30-40$ & + \\
\hline Oxytricha saltans (Cohn, 1866) Kahl, 1932 & $\mathrm{P}$ & $40-80 \times 15-30$ & + \\
\hline Parabirojimia similis Hu, Song \& Warren, 2002 & $\mathrm{~V}$ & $140-300 \times 30-50$ & + \\
\hline Pseudokeronopsis qingdaoensis Hu \& Song, 2000 & $\mathrm{~V}$ & $130-240 \times 50-70$ & ++ \\
\hline Thigmokeronopsis rubra Hu, Warren \& Song, 2004 & $\mathrm{~V}$ & $140-200 \times 40-50$ & ++ \\
\hline \multicolumn{4}{|l|}{ ORDER: Oligotrichida } \\
\hline Eutintinnus inquilinus (Müller, 1776) & $\mathrm{P}$ & $100-110 \times 30-40$ & + \\
\hline Strombidium sulcatum, Claparède \& Lachmann, 1858 & $\mathrm{P}$ & $30-45 \times 30-40$ & + \\
\hline
\end{tabular}

phrya lyngbyi, Pseudovorticella sinensis, Thigmokeronopsis rubra, Zoothamnium duplicatum and $Z$. plumula. The first 5 species occurred in more than one season while the last 7 species appeared in significant numbers during only 1 season (Fig. 5).

\section{Temporal patterns of community structure}

Cluster analysis based on square root transformed abundances resulted the 22 samples falling into 3 groups at a $12 \%$ similarity level (analysis of similarities 


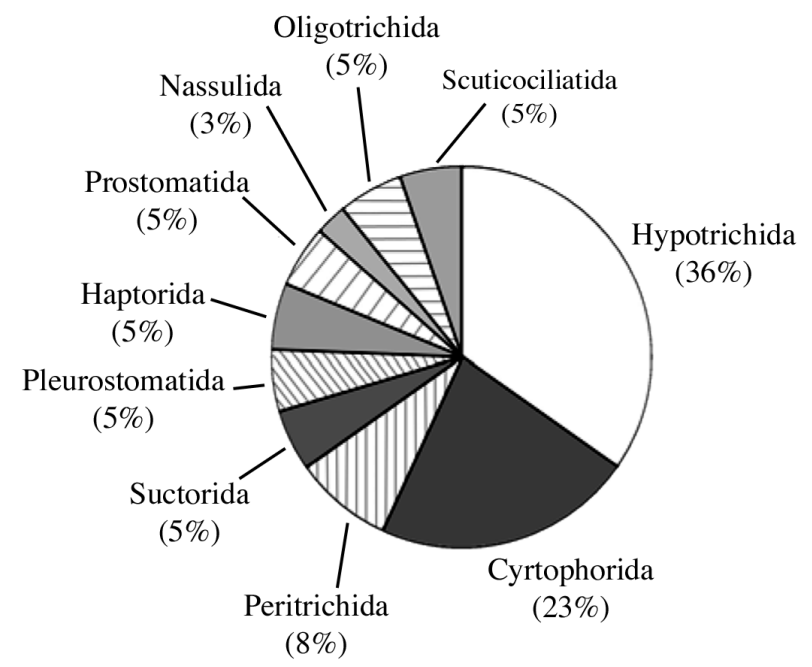

Fig. 2. Composition of periphytic ciliate communities; the percentage of the total number of species recorded throughout the period of sampling is shown for each order
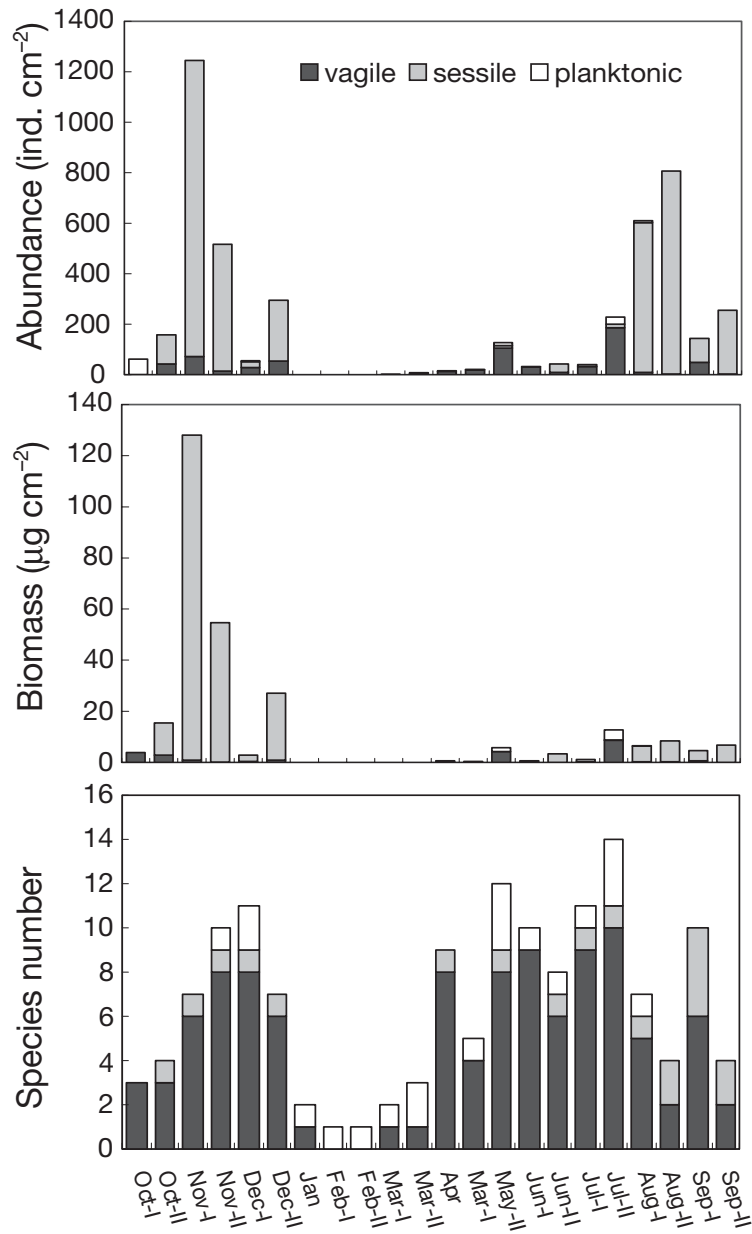

Fig. 3. Temporal variations of abundance, biomass and species number of vagile, sessile and planktonic ciliates in colonized biofilms. Two samples collected in 1 mo with an interval of $15 \mathrm{~d}$ were referred to as month-I and month-II
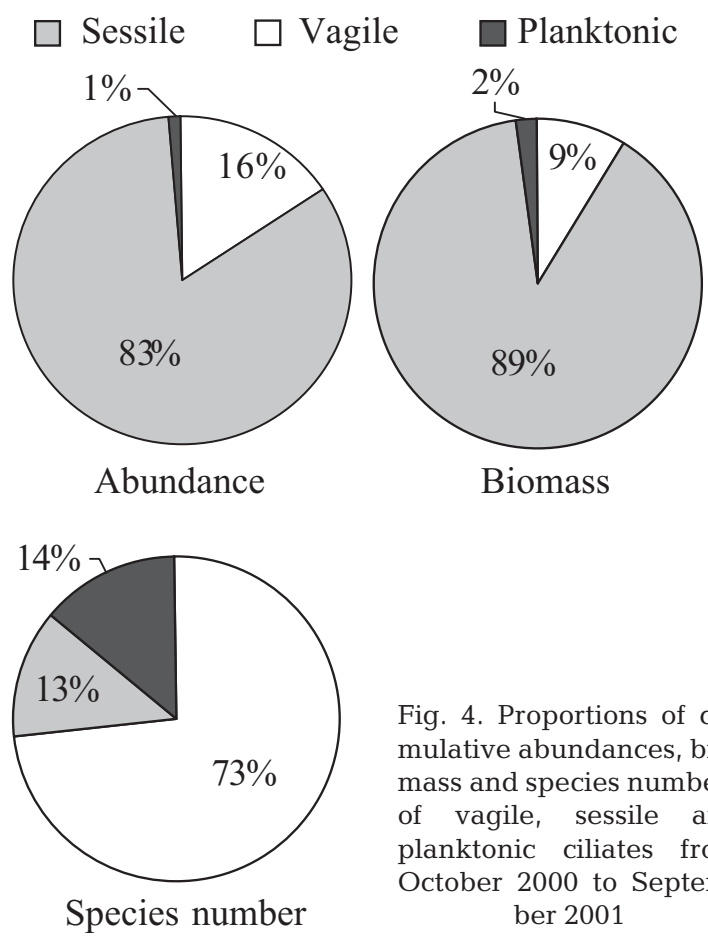

Fig. 4. Proportions of cumulative abundances, biomass and species numbers of vagile, sessile and planktonic ciliates from October 2000 to September 2001

[ANOSIM], p < 0.001): group I was composed of the winter month samples (Jan, Feb-I, Feb-II, Mar-I and Mar-II); group II, the 2 August samples (Aug-I and Aug-II); and group III, the rest of the samples (Fig. 6). Furthermore, at $19 \%$ similarity level, group III are clustered into 3 subgroups: IIIa, IIIb and IIIc (see Fig. 7). The MDS ordination shows a temporal distribution of samples in agreement with the dendrogram with the 3 groups appearing at separate locations on the plot (Fig. 7).

\section{Linking biota to environmental factors}

Table 3 summarizes the correlations between the various environmental parameters and species diversity, species evenness and species richness, excluding the 5 samples collected in winter (Jan, Feb-I, Feb-II, Mar-I, Mar-II) because of the lack of organisms on the slides. All 3 indices show significant positive relationships with water turbidity and $\mathrm{NO}_{2}-\mathrm{N}$, while significant correlations between species richness and nutrients such as $\mathrm{NH}_{3}-\mathrm{N}$, DIN and SRP are also noted.

Correlations between abundance of dominant species and environmental factors are shown in Table 4. Significant positive relationships were found between Amphileptus litonotiformis and $\mathrm{NO}_{3}-\mathrm{N}(\mathrm{r}=0.52$, $\mathrm{p}<$ 0.05), and between Hartmannula angustipilosa and $\mathrm{NH}_{3}-\mathrm{N}(\mathrm{r}=0.57, \mathrm{p}<0.05)$; the suctorian Corynophrya lyngbyi was positively correlated to $\mathrm{pH}$ value $(\mathrm{r}=0.49$, 


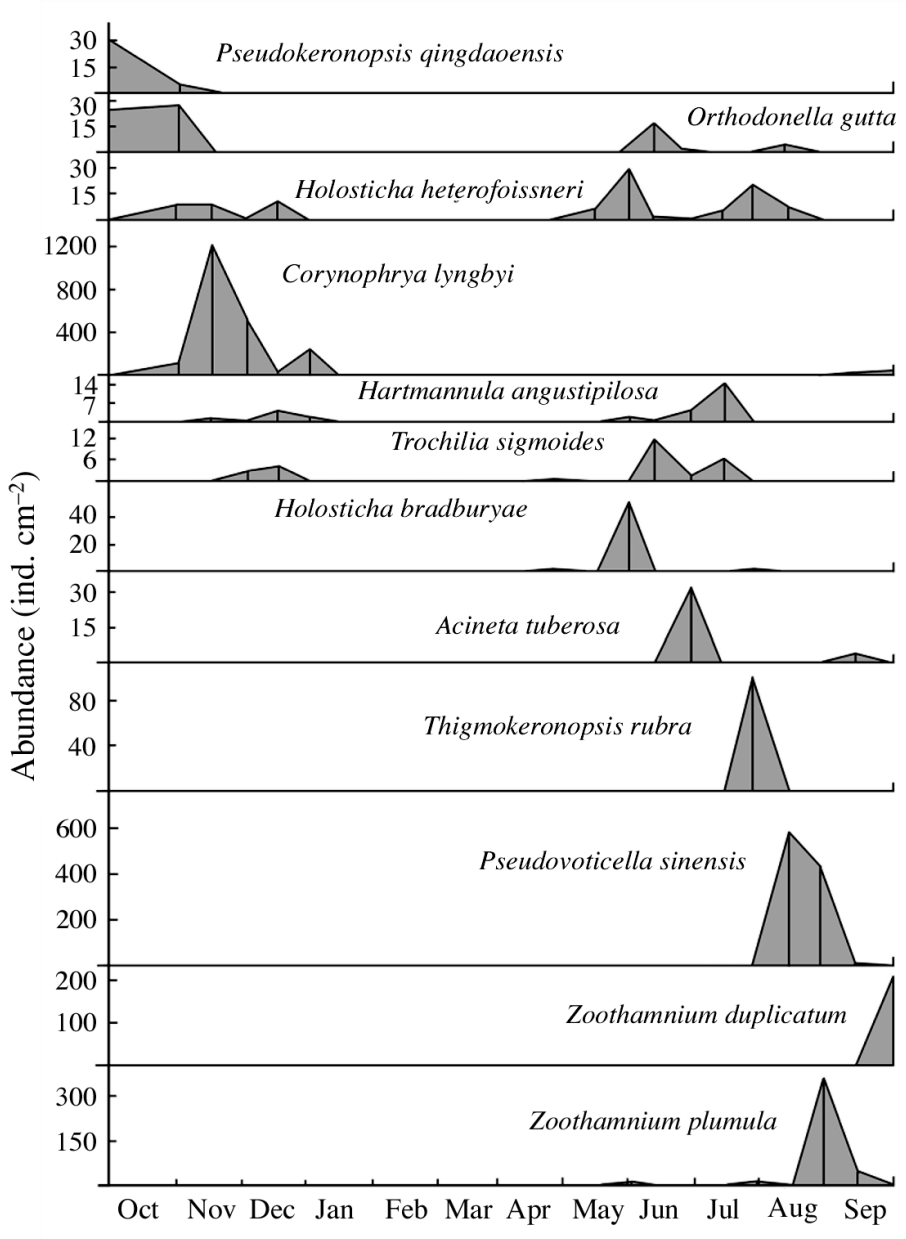

Fig. 5. Abundances (ind. $\mathrm{cm}^{-2}$ ) and temporal distribution of the 12 dominant ciliate species

$\mathrm{p}<0.05)$; Orthodonella hamatus showed a strong significant positive relationship with water temperature $(\mathrm{r}=0.70, \mathrm{p}<0.01)$; Pseudokeronopsis qingdaoensis correlated with SRP with high level of significance $(r=0.74, p<0.01)$, and also with water temperature $(\mathrm{r}=0.59, \mathrm{p}<0.05)$; there was a strong negative relationship between Pseudovorticella sinensis and salinity $(\mathrm{r}=-0.70, \mathrm{p}<0.01)$ and DO $(\mathrm{r}=-0.53, \mathrm{p}<0.05)$; there was a significant positive correlation between Zoothamnium duplicatum and SRP $(r=0.52, p<0.05)$.

For all the 22 samples collected over the year, the top 6 correlations between biota and environmental variables, established by BIOENV analysis, are dominated by temperature and nutrients (Table 5). The highest correlation occurs with the combination of 3 variables: temperature, $\mathrm{NO}_{2}-\mathrm{N}$ and $\mathrm{NO}_{3}-\mathrm{N}$. Another BIOENV analysis for 17 samples of biota (with the 5 winter samples excluded) and environmental variables showed a similar result: temperature, nutrients and salinity are all closely correlated to the community structure of periphytic ciliates (Table 5).

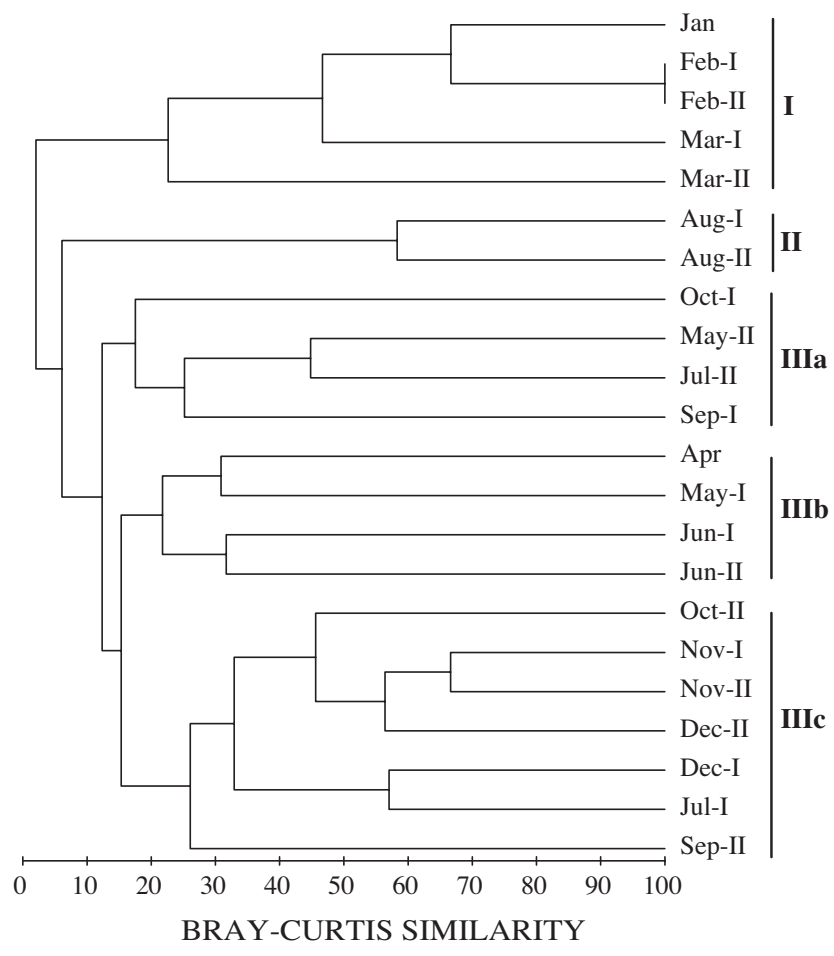

Fig. 6. Dendrogram of 22 samples, using group-average clustering from Bray-Curtis similarities on square root transformed abundances. I = group I; II = group II; IIIa, b, $\mathrm{c}=$ subgroup a, b, c in group III (see 'Results' for details). Two samples collected in 1 mo with an interval of $15 \mathrm{~d}$ were referred to as month-I and month-II

Periphytic community of ciliates $($ Stress $=0.12)$

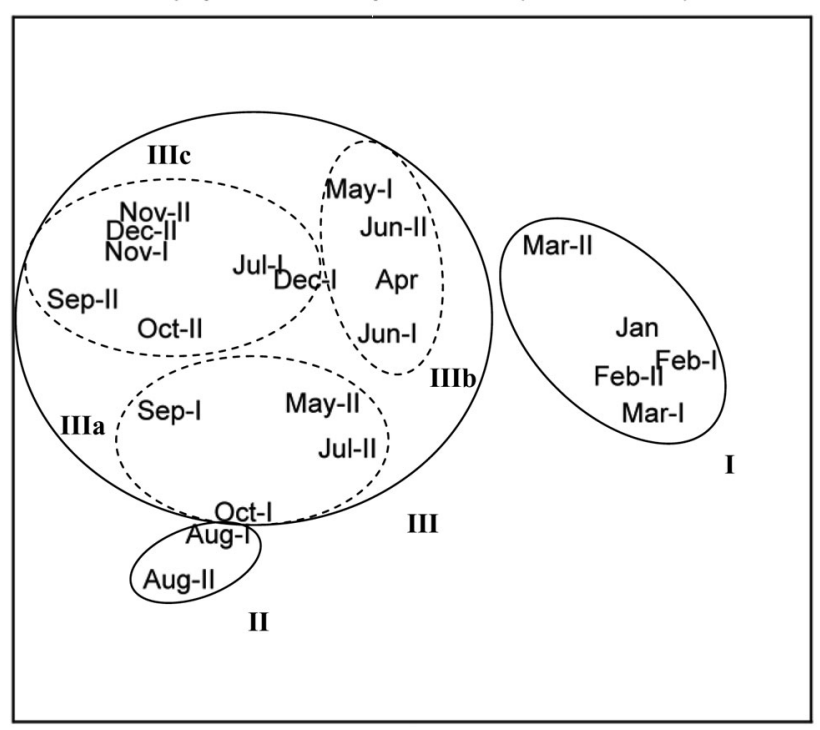

Fig. 7. Multidimensional scaling ordination of 22 samples for abundance data. Groups established from the cluster analysis are indicated (continuous line at $12 \%$ similarity level and discontinuous line at $19 \%$ similarity level). Stress $=0.12$ corresponds to a good ordination with no real prospect of a misleading interpretation 
Table 3. Correlation between environmental factors $(\mathrm{DIN}=$ dissolved inorganic nitrogen; see Table 1 for other abbreviations) and species diversity $\left(H^{\prime}\right)$, species evenness $(J)$, species richness $(d)$, abundance, biomass and biomass/abundance ratio (B/A) of the ciliate community. ${ }^{*} \mathrm{p}<0.05 ;{ }^{* *} \mathrm{p}<0.01$

\begin{tabular}{|lcccccc|}
\hline & $H^{\prime}$ & $J$ & $d$ & Abundance & Biomass & B/A \\
\hline $\mathrm{T}$ & -0.04 & 0.13 & -0.11 & 0.01 & 0.08 & 0.31 \\
$\mathrm{~S}$ & 0.28 & $0.46^{*}$ & 0.04 & -0.20 & 0.09 & 0.35 \\
$\mathrm{pH}$ & -0.28 & -0.03 & -0.34 & 0.15 & 0.47 & $0.56^{*}$ \\
$\mathrm{Tur}$ & $-0.71^{* *}$ & $-0.75^{* *}$ & $-0.53^{*}$ & 0.34 & 0.28 & 0.34 \\
$\mathrm{NO}_{2}-\mathrm{N}$ & $-0.59^{*}$ & $-0.55^{*}$ & $-0.49^{*}$ & 0.40 & 0.32 & 0.29 \\
$\mathrm{NH}_{3}-\mathrm{N}$ & 0.40 & 0.18 & $0.50^{*}$ & -0.26 & -0.32 & $-0.50^{*}$ \\
$\mathrm{NO}_{3}-\mathrm{N}$ & 0.32 & 0.22 & 0.34 & 0.31 & 0.32 & 0.33 \\
$\mathrm{DIN}$ & 0.35 & 0.18 & 0.46 & -0.22 & -0.27 & -0.46 \\
$\mathrm{SRP}$ & -0.33 & -0.01 & $-0.53^{*}$ & -0.04 & -0.01 & 0.04 \\
$\mathrm{DIN}+\mathrm{SRP}$ & 0.27 & 0.14 & 0.33 & -0.24 & -0.3 & $-0.48^{*}$ \\
$\mathrm{DO}$ & -0.03 & 0.04 & -0.03 & 0.03 & 0.44 & $0.60^{*}$ \\
$\mathrm{Chl} a$ & 0.25 & 0.18 & 0.29 & -0.20 & -0.45 & $-0.58^{*}$ \\
\hline
\end{tabular}

\section{DISCUSSION}

\section{Sampling strategy}

Biological colonization of a new artificial substrate is a dynamic process, the primary stage of which generally exhibits the following succession: at first, bacteria colonize the slide, followed by diatoms and autotrophic flagellates; the next groups are bacterivorous, vagile species of amoebae and ciliates; then larger species with a broader feeding spectrum and sessile feeders occur (Railkin 1995, Strüder-Kypke 1999). During the primary colonization process, the number of species generally increases and then equilibrates, following the MacArthur-Wilson equilibrium model (MacArthur \& Wilson 1967, Franco et al. 1998). Once equilibrium of immigration ends, the early and late interactive phases follow, during which internal factors such as competition and predation pressure become more important (Cairns \& Henebry 1982, Railkin 1995).

The time taken for primary colonization to reach equilibrium greatly depends on environmental factors such as water temperature (seasonality) and trophic conditions. StrüderKypke (1999) found that the primary colonization in bog lakes reaches its climax after $6 \mathrm{wk}$ during winter months but after only $4 \mathrm{wk}$ in summer. Equilibrium was reached after 1 mo for the mesotrophic White Sea (Railkin 1995), up to $12 \mathrm{wk}$ in oligotrophic lakes (Bamforth 1982), and on average within 2 wk in eutrophic habitats (Wilbert 1969). These findings suggest that, given certain parameters remain constant (e.g. artificial substrate, target habitat and period of exposure), the colonized community is possibly a function of at least 2 environmental aspects, namely seasonality and trophic conditions.

During our 1 yr survey, glass slides were exposed for a fixed period of $15 \mathrm{~d}$, which is sufficient for optimal ciliate colonization in most months of the year (Persoone 1968, Agamaliev 1974). However, few or even no typical periphytic ciliates were found in the winter samples: Jan, Feb-I, Feb-II, Mar-I and Mar-II. The most likely explanation for this is that when the water temperatures were extremely low $\left(3.5\right.$ to $\left.6^{\circ} \mathrm{C}\right)$, the time to reach equilibrium was probably far longer than $2 \mathrm{wk}$.

Glass slides proved to be a robust, inexpensive and reliable method for collecting periphyton ciliates. Other forms of artificial substrate that are commonly used to collect protozoa communities for bioassess-

Table 4. Correlation between abundance of dominant ciliates and environmental factors (see Table 1 for abbrevations). ${ }^{*} \mathrm{p}<0.05 ;{ }^{* *} \mathrm{p}<0.01$

\begin{tabular}{|c|c|c|c|c|c|c|c|c|c|c|}
\hline & $\begin{array}{c}\mathrm{T} \\
\left({ }^{\circ} \mathrm{C}\right)\end{array}$ & $\begin{array}{c}\mathrm{S} \\
(\mathrm{psu})\end{array}$ & $\mathrm{pH}$ & $\begin{array}{c}\text { Tur } \\
\text { (NTU) }\end{array}$ & $\begin{array}{l}\mathrm{NO}_{2}-\mathrm{N} \\
\left(\mathrm{mg} \mathrm{l}^{-1}\right)\end{array}$ & $\begin{array}{l}\mathrm{NO}_{3}-\mathrm{N} \\
\left(\mathrm{mg} \mathrm{l}^{-1}\right)\end{array}$ & $\begin{array}{r}\mathrm{NH}_{3}-\mathrm{N} \\
\left(\mathrm{mg} \mathrm{l}^{-1}\right)\end{array}$ & $\begin{array}{c}\mathrm{SRP} \\
\left(\mathrm{mg} \mathrm{l}^{-1}\right)\end{array}$ & $\begin{array}{c}\mathrm{DO} \\
\left(\mathrm{mg} \mathrm{l}^{-1}\right)\end{array}$ & $\begin{array}{c}\text { Chl a } \\
\left(\mu \mathrm{g} \mathrm{l}^{-1}\right)\end{array}$ \\
\hline Acineta tuberosa & 0.10 & 0.11 & -0.03 & -0.11 & -0.25 & -0.18 & 0.07 & -0.13 & -0.21 & 0.24 \\
\hline Amphileptus litonotiformis & -0.37 & -0.04 & -0.07 & 0.37 & -0.20 & $0.52^{*}$ & -0.14 & -0.19 & -0.04 & -0.30 \\
\hline Corynophrya lyngbyi & 0.05 & 0.10 & $0.49^{*}$ & 0.28 & 0.43 & 0.34 & -0.33 & -0.01 & 0.48 & -0.48 \\
\hline Hartmannula angustipilosa & 0.07 & -0.03 & -0.11 & -0.13 & -0.15 & -0.04 & $0.57^{*}$ & -0.29 & -0.12 & 0.10 \\
\hline Holosticha heterofoissneri & 0.20 & -0.11 & -0.29 & -0.33 & -0.10 & -0.32 & 0.36 & -0.35 & -0.02 & 0.19 \\
\hline Orthodonella hamatus & $0.70^{* *}$ & 0.33 & 0.46 & -0.22 & 0.14 & -0.14 & -0.21 & 0.40 & 0.16 & -0.14 \\
\hline Pseudokeronopsis qingdaoensis & $0.59^{*}$ & 0.23 & 0.39 & -0.14 & 0.25 & -0.03 & -0.26 & $0.74^{* *}$ & 0.19 & -0.20 \\
\hline Pseudovorticella sinensis & -0.01 & $-0.7^{* *}$ & -0.34 & 0.18 & 0.21 & 0.00 & 0.09 & -0.06 & $-0.53^{*}$ & 0.41 \\
\hline Thigmokeronopsis rubra & -0.10 & -0.10 & -0.42 & -0.09 & -0.22 & -0.30 & 0.42 & -0.22 & -0.08 & 0.22 \\
\hline Trochilia sigmoides & 0.22 & 0.07 & -0.13 & -0.16 & -0.17 & -0.17 & 0.10 & -0.20 & 0.06 & 0.15 \\
\hline Zoothamnium duplicatum & -0.07 & 0.11 & -0.24 & 0.00 & 0.27 & 0.27 & -0.17 & -0.19 & -0.37 & 0.20 \\
\hline Zoothamnium plumula & -0.27 & 0.04 & -0.05 & 0.29 & -0.05 & -0.05 & -0.16 & $0.52^{*}$ & -0.20 & -0.15 \\
\hline
\end{tabular}


Table 5. Summary of result from biota-environment (BIOENV) analysis, with the top 6 correlations corresponding to different variables ( $p=$ Spearman correlation coefficient). See Table 1 for abbreviations

\begin{tabular}{|c|c|c|c|c|}
\hline \multirow[t]{2}{*}{ Rank } & \multirow{2}{*}{$p$} & \multirow{2}{*}{$\begin{array}{l}22 \text { samples } \\
\text { Variables }\end{array}$} & \multicolumn{2}{|r|}{17 samples } \\
\hline & & & $p$ & Variables \\
\hline 1 & 0.588 & $\mathrm{~T}, \mathrm{NO}_{2}-\mathrm{N}, \mathrm{NO}_{3}-\mathrm{N}$ & 0.439 & $\mathrm{~T}, \mathrm{~S}, \mathrm{NO}_{2}-\mathrm{N}, \mathrm{NO}_{3}-\mathrm{N}, \mathrm{SRP}$ \\
\hline 2 & 0.581 & $\mathrm{~T}, \mathrm{NO}_{2}-\mathrm{N}$ & 0.425 & $\mathrm{~T}, \mathrm{~S}, \mathrm{NO}_{2}-\mathrm{N}, \mathrm{NO}_{3}-\mathrm{N}$ \\
\hline 3 & 0.536 & $\mathrm{~T}, \mathrm{NO}_{2}-\mathrm{N}, \mathrm{SRP}, \mathrm{NO}_{3}-\mathrm{N}$ & 0.420 & $\mathrm{~T}, \mathrm{~S}, \mathrm{NO}_{2}-\mathrm{N}, \mathrm{NH}_{3}-\mathrm{N} \mathrm{NO}_{3}-\mathrm{N}, \mathrm{SRP}$ \\
\hline 4 & 0.515 & $\mathrm{~T}, \mathrm{NO}_{2}-\mathrm{N}, \mathrm{NH}_{3}-\mathrm{N}$ & 0.416 & $\mathrm{~S}, \mathrm{NO}_{2}-\mathrm{N}, \mathrm{SRP}, \mathrm{NO}_{3}-\mathrm{N}$ \\
\hline 5 & 0.511 & $\mathrm{~T}, \mathrm{NO}_{2}-\mathrm{N}, \mathrm{SRP}$ & 0.410 & $\mathrm{~T}, \mathrm{~S}, \mathrm{NO}_{2}-\mathrm{N}, \mathrm{NH}_{3}-\mathrm{N}$ \\
\hline 6 & 0.508 & $\mathrm{NO}_{2}-\mathrm{N}, \mathrm{NO}_{3}-\mathrm{N}$ & 0.409 & $\mathrm{~T}, \mathrm{~S}, \mathrm{NO}_{2}-\mathrm{N}, \mathrm{NH}_{3}-\mathrm{N}, \mathrm{SRP}$ \\
\hline
\end{tabular}

ment include polyurethane foam units (PFU) (Pratt \& Kepner 1992, Xu et al. 2002). PFUs are particularly suited for investigating species numbers over an expanding time scale (e.g. 1, 2, 4, 8, 16 d). Such a strategy is, however, not so well suited for studies that involve long time-scales (e.g. 1 yr) or large number of sites because it is very demanding in terms of labour and time. In addition, squeezing PFUs may result in the failure to recover certain types of ciliates, e.g. sessile and highly thigmotactic species.

\section{Taxonomic composition}

In the present study, 37 species representing 30 genera and 10 orders of ciliates were detected. This result is similar to the previous report by Persoone (1968), who, using the same sampling method, found 30 ciliate species (belonging to 21 genera and 9 orders) in a polluted harbour at Ostend, Belgium, also over a period of 1 yr. Comparing the taxonomic compositions of the 2 communities, 5 species (Trochilioides recta, Acineta tuberosa, Corynophrya lyngbyi, Uronema marinum and Euplotes vannus) and 14 genera (accounting for $66.7 \%$ of genera recorded in the Ostend study) were found at both locations. Comparison at the order level indicates even higher similarity between the 2 faunas: 8 out of the 9 ciliate orders in Ostend were also present in the Qingdao samples. Over half the species in the Ostend samples were from the orders Hypotrichida (30\%) and Cyrtophorida (23.3\%). The same 2 orders accounted for similar proportions of the species composition in the present study (36 and $23 \%$, respectively; see Fig. 2).

A large number (130) of periphytic ciliates were found on a combination of submerged objects and glass slides in the Caspian Sea (Agamaliev 1974). Species in orders Hypotrichida (36.2\%) and Peritrichida $(18.5 \%)$ accounted for over half of the total. However, it should be noted that the higher species richness of periphytic ciliates in the Caspian Sea compared to the present study was almost certainly due to the larger number of samples (500) and the wider range of locations sampled.

Coppellotti \& Matarazzo (2000) investigated ciliate colonization on glass slides in the Lagoon of Venice and found 45 species representing 34 genera, $12(40 \%)$ of which were also found at Qingdao. Like the ciliate faunas of Qingdao, Ostend and the Caspian Sea, the Hypotrichida represented the largest proportion of species $(33 \%)$ in the Venice study, the second largest being the Peritrichida $(17.8 \%)$. Cyrtophorida accounted for only $2 \%$. In addition, 5 species of karyorelictids, namely Trachelocerca lacrymariae, T. multinucleata, Tracheloraphis gracilis, Remanella multinucleate and Geleia swedmarki, which are usually considered to be benthic species (Fenchel 1969), were also included on the species list. The depth at which the artificial substrate was submerged might explain this finding since most samples of the Lagoon of Venice were recovered from just 60 $\mathrm{cm}$ above the bottom (Coppellotti \& Matarazzo 2000).

Considering the clear links between the ecological niches of protists and their morphology (Fenchel 1986, 1987), Franco et al. (1998) classified various taxonomic orders of ciliates into feeding categories, based on 3 parameters: the structure and function of the oral apparatus; the way the ciliate collects its food; and the size of the captured food particles. The taxonomic order itself, however, circumscribes certain aspects of the morphology of any given ciliate and hence, to a certain extent, provides a clue to its ecology. In our study, the predominance of the dorsoventrally flattened hypotrich species is almost certainly due to this adaptation of protozoa that crawl on surfaces (Fenchel 1987). The bilaterally flattened cyrtophorids were the second largest group in both the Ostend and Qingdao surveys, but only a minor component of the ciliate communities in the Venice Lagoon and Caspian Sea areas (Agamaliev 1974, Coppellotti \& Matarazzo 2000). This is in contrast to the situation in freshwater habitats, where the peritrichs usually dominate the periphytic communities (Shen et al. 1990, Song \& Chen 1999).

\section{Univariate and multivariate analyses}

Univariate correlation analysis for community and environmental factors was carried out on data sets omitting the 5 winter samples. Species diversity, evenness and richness indices are commonly employed in community studies and are amenable to simple statisti- 
cal analysis (Magurran 1991, Ismael \& Dorgham 2003). In our case, however, diversity and evenness generally failed to show significant relationships with environmental factors whereas species richness did. A similar finding was demonstrated in a diatom community study which also involved the use of artificial substrates (Vaultonburg \& Pederson 1994).

All 3 indices sharply decreased in the Aug-I sample when Pseudovorticella sinensis dominated the community. This may have been due to the low salinity and DO, both of which showed highly significant negative correlations with the abundances of other peritrich species such as Zoothamnium duplicatum.

The ratio of biomass to abundance (B/A) of the community, i.e. the mean body-size of species in a sample, showed strong negative correlations with nutrients. That is to say, the higher nutrients load, the more small-sized species were present. This is consistent with the use of abundance/biomass comparison (ABC) plots to determine levels of disturbance (Warwick 1986). This method, which is usually for benthic macrofauna studies, might thus also be suitable for biomonitoring using periphytic ciliate communities.

Multivariate analyses were more sensitive than univariate ones for detecting changes in community structure. For example, the 2 samples in August (Group II) comprised a distinct cluster at a similarity level of $12 \%$ (Fig. 6) that corresponded to the decrease in salinity and the increase in concentrations of $\mathrm{NO}_{3}-\mathrm{N}_{1} \mathrm{NO}_{2}-\mathrm{N}$ and SRP. The separation of other groups basically reflects seasonal effects, but with few exceptions (e.g. Jul-I was grouped together with autumn samples in subgroup IIIc). This indicates other physico-chemical variables also play roles in the differentiation of community structures.

The subsequent BIOENV confirms that temperature is the most important factor influencing the structure of the periphytic ciliate community, based either on the entire year's samples or on those with the winter data omitted. Likewise, nutrients were always among the top combinations of variables in both cases whereas salinity was only occasionally an important factor, particularly when the data from the winter samples were omitted from the analysis. Since many ciliates are consumers of bacteria and algae in microbial loops, nutrients may affect the growth and structure of attached bacteria and diatoms and further indirectly affect the communities of periphytic ciliate on glass slides.

Multivariate analysis was also employed but failed to reveal any relationships between periphytic ciliate community on glass slides and environment with pollution of heavy metals (Coppellotti \& Matarazzo 2000). They classified ciliates into 3 groups (i.e. suctoria, peritrichs and vagile ciliates) rather than investigating each species individually. This significantly reduced the dimensions of the biota matrix and inevitably weakened the sensitivity of the multivariate analysis.

In summary, our studies demonstrate that variations of periphytic ciliate communities were not only seasonal but were also highly correlated to the concentrations of dissolved nutrients in the water and hence, to some extent, show potential for the assessment of water quality. Further studies, e.g. site-by-site comparisons of community responses to specific environmental stress such as heavy metals or organic pollutants, are needed to further explore the possibility of using periphytic ciliates in marine water biomonitoring.

Acknowledgements. This work was supported by 'the National Science Foundation of China' (Project No. 40246021, 30430090) and a Royal Society Joint Project Programme (No. Q822). Thanks are due to Dr. W. Zhang for constructive suggestions on early version of the manuscript.

\section{LITERATURE CITED}

Agamaliev FG (1974) Ciliates of the solid surface overgrowth of the Caspian Sea. Acta Protozool 13:53-83

Al-Rashid KAS, Sleigh MA (1995) Distribution and abundance of interstitial ciliates in Southampton water in relation to physicochemical conditions, metal pollution and availability of food organisms. Estuar Coast Shelf Sci 41:61-80

APHA (American Public Health Association) (1989) Standard methods for examinations of water and wastewater, 17 edn. APHA, Washington DC

Azam F, Fenchel T, Field JG, Gray JS, Meyer-Reil LA, Thingstad F (1983) The ecological role of water-column microbes in the sea. Mar Ecol Prog Ser 10:257-263

Baldock B, Baker J, Sleigh MA (1983) Abundance and productivity of protozoa in chalk streams. Holarctic Ecol 6: 238-246

Bamforth SS (1982) The variety of artificial substrates used for microfauna. In: Cairns J Jr (ed) Artificial substrates. Ann Arbor Science Publishers, Ann Arbor, MI, p 115-130

Cairns J Jr, Henebry MS (1982) Interactive and noninteractive protozoa colonization process. In: Cairns J Jr (ed) Artificial substrates. Ann Arbor Science Publishers, Ann Arbor, MI, p 27-30

Cairns J Jr, Lanza GR, Parker BC (1972) Pollution related to structural and functional changes in aquatic communities with emphasis on freshwater algae and protozoa. Proc Acad Nat Sci Phila 124:79-127

Cairns J Jr, Yongue WH Jr (1968) The distribution of freshwater protozoa on a relatively homogenous substrate. Hydrobiologia 31:65-72

Carey PG (1992) Marine interstitial ciliates. An illustrated key. Chapman and Hall, London

Caron DA, Goldmann JC (1990) Protozoan nutrient regeneration. In: Capriulo GM Jr (ed) Ecology of marine Protozoa. Oxford University Press, New York

Clarke KR, Ainsworth M (1993) A method of linking multivariate community structure to environmental variables. Mar Ecol Prog Ser 92:205-219

Clarke KR, Warwick RM (1994) Change in marine communities: an approach to statistical analysis and interpretation. Plymouth Marine Laboratory, Natural Environment Research Council, Plymouth 
Coppellotti O (1998) Sensitivity to copper in a ciliate as a possible component of biological monitoring in the Lagoon of Venice. Archs Environ Contamin Toxicol 35:417-425

Coppellotti O, Matarazzo P (2000) Ciliates colonization of artificial substrates in the Lagoon of Venice. J Mar Biol Assoc UK 80:419-427

Corliss JO (1979) The ciliated protozoa. Characterization, classification and guide to the literature, 2nd edn. Pergamon Press, Oxford

Dale T (1991) Protists and pollution - with an emphasis on planktonic ciliates and heavy metals. In: Reid PC, Turley $\mathrm{CM}$, Burkill PH (eds) Protozoa and their role in marine processes. NATO ASI Series, Vol. 25. Springer-Verlag, Berlin, p 115-130

Fenchel T (1969) The ecology of marine microbenthos. IV. Structure and function of the benthic ecosystem, its chemical and physical factors and the microfauna communities with special reference to the ciliated protozoa. Ophelia 6: $1-182$

Fenchel T (1986) Protozoan filter feeding. Prog Protistol 1: 65-113

Fenchel T (1987) Ecology of Protozoa. Springer-Verlag, Berlin

Finlay BJ, Bannister P, Stewart J (1979) Temporal variation in benthic ciliates and the application of association analysis. Freshw Biol 9:45-53

Finlay BJ, Berninger UG, Clarke KJ, Cowling AJ, Hindle RM, Rogerson A (1988) On the abundance and distribution of protozoa and their food in a productive freshwater pond. Eur J Protistol 23:205-217

Foissner W (1987) Soil Protozoa: fundamental problems, ecological significance, adaptations in ciliates and testaceans, bioindicators and guide to the literature. Prog Protistol 2: 69-212

Foissner W, Unterweger A, Henschel T (1992) Comparison of direct stream bed and artificial substrate sampling of ciliates (Protozoa, Ciliophora) in a mesosaprobic river. Limnologica 22:97-104

Foissner W, Berger H, Schaumburg J (1999) Identification and ecology of limnetic plankton ciliates. Informationsberichte des Bayer. Landesamtes für Wasserwirtschaft 3/99:1-793

Franco C, Esteban G, Téllez C (1998) Colonization and succession of ciliated protozoa associated with submerged leaves in a river. Limnologica 28:275-283

Fried J, Mayr G, Berger H, Traunspurger W, Psenner R, Lemmer H (2000) Monitoring protozoa and metazoa biofilm communities for assessing wastewater quality impact and reactor up-scaling effects. Wat Sci Tech 41:309-316

Gong J, Song W (2004a) Description of a new marine cyrtophorid ciliate, Dysteria derouxi nov. spec., with an updated key to 12 well-investigated Dysteria species (Ciliophora, Cyrtophorida). Eur J Protistol 40:13-19

Gong J, Song W (2004b) Morphology and infraciliature of 2 marine species of Hartmannula (Protozoa, Ciliophora, Cyrtophorida), from scallop-farming waters off Qingdao (Tsingtao), China. J Nat Hist 38:1327-1337

Gong J, Song W, Hu X, Ma H, Zhu M (2001) Morphology and infraciliature of Holosticha bradburyae nov. spec. (Ciliophora, Hypotrichida) from the Yellow Sea, China. Hydrobiologia 464:63-69

$\mathrm{Hu}$ X, Song W, Warren A (2002) Observations on the morphology and morphogenesis of a new marine urostylid ciliate, Parabirojimia similis nov. gen., nov. spec. (Protozoa, Ciliophora, Hypotrichida). Eur J Protistol 38:351-364

Hu X, Gong J, Song W (2003) Pathogenic ciliates in scallopfarming waters. In: Song W, Zhao Y, Xu K, Hu X, Gong J (eds) Pathogenic Protozoa in mariculture. Science Press, Beijing, p 145-178
Hu X, Warren A, Song W (2004) Observation on the morphology and morphogenesis of a new marine hypotrich ciliate (Ciliophora, Hypotrichida) from China. J Nat Hist 38: 1059-1069

Ismael AA, Dorgham MM (2003) Ecological indices as a tool for assessing pollution in El-Dekhaila Harbour (Alexandria, Egypt). Oceanologia 45:121-131

Jeffrey SW, Humphrey GF (1975) New spectrophotometric equations for determining chlorophyls $a, b, c 1$ and $c 2$ in higher plants, algae and natural phytoplankton. Biochem Physiol Pflanzen 167:191-194

Ji D, Song W, Al-Rasheid KAS (2003) Description of a marine peritrichous ciliate, Pseudovorticella sinensis n. sp. (Ciliophora, Peritrichia) from China. J Eukaryot Microbiol 50: 360-365

Kahl A (1931) Urtiere oder Protozoa I: Wimpertiere oder Ciliata (Infusoria) 2. Holotricha außer den im 1. Teil behandelten Prostomata. Tierwelt Dtl 21:181-398

Lee JJ (1986) Protozoa as indicators of ecosystems. Insect Sci Appl 7:349-353

Lin X, Gong J, Song W (2004) Morphological studies on a new species of Orthodonella, with redescription of O. gutta (Cohn, 1866) Kahl, 1931 (Protozoa: Ciliophora: Synhymeniida) from coastal water off Qingdao, China. J Nat Hist 38:2001-2011

Ma C, Sun H, Wang X, Ying L, Peng Z (1997) Assessment of situation and trend of water quality in coastal area of the Yellow Sea. Mar Environ Sci 16:32-37 (in Chinese with English abstract)

MacArthur RH, Wilson EO (1967) The theory of island biogeography. Monographs in population ecology, I. Princeton University Press, Princeton, NJ

Magurran AE (1991) Ecological diversity and its measurement. Chapman and Hall, London

Margalef R (1968) Perspectives in ecological theory. University of Chicago Press, Chicago, IL

Martín-Cereceda M, Serrano S, Guinea A (2001) Biofilm communities and operational monitoring of a rotating biological contractor system. Wat Air Soil Pollut 126:193-206

Mohr JL (1952) Protozoa as indicators of pollution. Sci Month $1: 7-9$

Patterson DJ, Larsen J, Corliss JO (1989) The ecology of heterotrophic flagellates and ciliates living in marine sediments. Prog Protistol 3:185-277

Persoone G (1968) Ecologie des Infusoires dans les salissures de substrats immerges dans un port de mer. I. Le film primaire et le recouvrement primaire. Protistologica 4:187-194

Pielou EC (1969) An introduction to mathematical ecology. John Wiley\& Sons, New York

Pratt JR, Balczon JM (1992) Biomonitoring using protozoans. In: Lee JJ, Soldo AT (eds) Protocols in protozoology. Society of Protozoologists,Lawrence, KS, p B-12.1-B-12.3

Pratt JR, Crains J Jr (1985) Functional groups in the protozoa: roles in differing ecosystems. J Protozool 32:415-423

Pratt JR, Kepner RL (1992) Collecting aufwuchs on artificial substrates. In: Lee JJ, Soldo AT (eds) Protocols in Protozoology. Society of Protozoologists, p B-9.1-B-9.7

Primc-Habdija B, Habdija I, Plenkoviç-Moraj A (2001) Tufa deposition and periphyton overgrowth as factors affecting the ciliate community on travertine barriers in different current velocity conditions. Hydrobiologia 457:87?96

Putt M, Stoecker DK (1989) An experimentally determined carbon :volume ratio for marine 'oligotrichous' ciliates from estuarine and coastal waters. Limnol Oceanogr 34: 1097-1103

Railkin AI (1995) Heterotrophic flagellates on artificial substrates in the White Sea. Cytology 37:951-957 
Shannon CE, Weaver W (1963) The mathematical theory of communication. University of Illinois Press, Urbana, IL

Shen Y, Zhang Z, Gong X, Gu M, Shi Z, Wei Y (1990) Modern biomonitoring techniques using freshwater microbiota. China Architecture and Building Press, Beijing (in Chinese)

Sherr EB, Sherr BF (1987) High rates of consumption of bacteria by pelagic ciliates. Nature 325:710-711

Song W, Wilbert N (1995) Benthische Ciliaten des Süsswassers. In: Röttger R (ed) Praktikum der Protozoologie. Gustav Fischer Verlag, Stuttgart, p 156-168

Song W, Chen Z (1999) Ecological studies on Aufwuchs ciliates from a eutrophic freshwater pond. In: Song W (ed) Progress in protozoology. Qingdao Ocean University Press, Qingdao, p 325-362 (in Chinese)

Strüder-Kypke MC (1999) Periphyton and sphagnicolous protists of dystrophic bog lakes (Brandenburg, Germany). I. Annual cycles, distribution and comparison to other lakes. Limnologica 29:393-406

Strüder-Kypke MC, Schönborn W (1999) Periphyton and sphagnicolous protists of dystrophic bog lakes (Brandenburg, Germany). II. Characteristic species and trophic of the lakes. Limnologica 29:407-424

Talling JF, Driver D (1961) Some problems in the estimation of

Editorial responsibility: Fereidoun Rassoulzadegan, Villefranche-sur-Mer, France chlorophyll-a in phytoplankton. In: Oi P (ed) Proceedings of the conference on primary productivity measurement, marine and freshwater at the University of Hawaii, August. US Atomic Energy Commission, TID-7633, Washington, DC, p 142-146

Vaultonburg DL, Pederson CL (1994) Spatial and temporal variation of diatom community structure in east-central Illinois streams. Trans Illinois State Acad Sci 87:9-27

Warwick RM (1986) A new method for detecting pollution effects on marine macrobenthic communities. Mar Biol 92: 557-562

Weitere M, Schmidt-Denter K, Arndt H (2003) Laboratory experiments on the impact of biofilms on the plankton of a large river. Freshw Biol 48:1983-1992

Wilbert N (1969) Ökologische Untersuchung der Aufwuchsund Planktonciliaten eines eutrophen Weihers. Arch Hydrobiol (Suppl) 35:411-518

Wilbert N (1975) Eine verbesserte Technik der Protargolimprägnation für Ciliaten. Mikrokosmos 64:171-179

Winberg GG (1971) Methods for the estimation of production of aquatic animals. Academic Press, New York

Xu K, Choi JK, Yang EJ, Lee KC, Lei Y (2002) Biomonitoring of coastal pollution status using protozoan communities with a modified PFU method. Mar Pollut Bull 44:877-886

Submitted: September 8, 2004; Accepted: March 7, 2005

Proofs received from author(s): May 21, 2005 